Akuntansi dan Manajemen

Vol. 16, No. 2, 2021, Hal. 123-141

\title{
Analisis Determinan Agresivitas Pajak Pada Perusahaan Sektor Industri
}

\author{
Zona Atasa Azizah Sabna1, Sartika Wulandari² \\ 1 Jurusan Akuntansi, Universitas Stikubank Semarang \\ Email: zonasabna99@gmail.com \\ 2Jurusan Akuntansi, Universitas Stikubank Semarang \\ Email: sartikawulan@edu.unisbank.ac.id
}

\begin{abstract}
This research aimed to analyze the factors affecting tax aggressiveness. The variables used were leverage, intensity of inventory, intensity of fixed asset, profitability, and liquidity. The approach used was quantitative with secondary data sources obtained from annual financial reports on the Indonesia Stock Exchange (IDX). The population of this research were 53 manufacturing industry companies listed on the Indonesia Stock Exchange (IDX) in the 2017-2020 period using the purposive sampling method. Based on the purposive sampling method, 84 samples were obtained from 21 manufacturing industry companies listed on the IDX for the 2017-2020 period. The data analysis technique in this research used panel data with the Eviews Program as a tool. The results obtained indicated that the factors affecting tax aggressiveness were the variable intensity of fixed assets and profitability. This research states that the intensity of fixed assets has a negative and significant effect on tax aggressiveness, while profitability has a positive and significant effect on tax aggressiveness. Meanwhile, the factors that have no effect on tax aggressiveness are the variables of leverage, intensity of inventory, and liquidity.
\end{abstract}

Keywords: Tax Aggressivenes, Leverage, and Liquidity

\begin{abstract}
ABSTRAK
Penelitian ini bertujuan untuk menganalisis faktor-faktor yang mempengaruhi agresivitas pajak. Variabel yang digunakan antara lain leverage, intensitas persediaan, intensitas aset tetap, profitabilitas, dan likuiditas. Pendekatan yang digunakan adalah kuantitatif dengan sumber data sekunder yang diperoleh dari laporan keuangan tahunan pada Bursa Efek Indonesia (BEI). Populasi penelitian ini yaitu 53 perusahaan manufaktur sektor industri yang terdaftar di BEI pada periode 2017-2020 dengan metode purposive sampling. Berdasarkan metode purposive sampling diperoleh 84 sampel dari 21 perusahaan manufaktur sektor industri yang terdaftar di BEI periode 2017-2020. Teknik analisis data pada penelitian ini menggunakan data panel dengan alat bantu program Eviews. Hasil penelitian yang diperoleh menunjukkan bahwa faktor yang mempengaruhi agresivitas pajak adalah variabel intensitas aset tetap dan profitablitas. Penelitian ini menyatakan bahwa intensitas aset tetap berpengaruh negatif dan signifikan terhadap agresivitas pajak, sedangkan profitabilitas berpengaruh positif dan signifikan terhadap agresivitas pajak. Sementara faktor yang tidak berpengaruh terhadap agresivitas pajak adalah variabel leverage, intensitas persediaan, dan likuiditas.
\end{abstract}

Kata kunci: Agresivitas Pajak, Leverage, dan Likuiditas 


\section{Pendahuluan}

Negara Indonesia merupakan salah satu negara berkembang dengan jumlah penduduk yang tinggi di dunia dan memiliki kekayaan akan sumber daya yang melimpah. Indonesia menjadi kawasan lalu lintas perdagangan dunia karena letak geografisnya yang cukup strategis. Hal ini dapat menjadi daya tarik para pengusaha untuk mendirikan perusahaan di Indonesia. Semakin bertambahnya perusahaan yang ada memberikan keuntungan bagi negara dalam peningkatan pendapatan. Pendapatan utama negara Indonesia salah satunya berasal dari sektor pajak. Bagi negara pajak merupakan penyumbang pendapatan terbesar yang sangat diperhatikan oleh pemerintah secara khusus. Penerimaan pajak yang besar membuat pemerintah berusaha dalam memaksimalkan penerimaan tersebut. Usaha yang dilakukan pemerintah untuk menaikan target pajak setiap tahun dengan tujuan melancarkan roda pemerintah melalui berbagai program agar dapat meningkat kesejahteraan rakyat.

Bagi perusahaan, pajak merupakan suatu beban yang akan mengurangi laba bersih dari perusahaan tersebut. Pajak dalam perusahaan dianggap sebagai beban dan biaya, sehingga perusahaan membutuhkan usaha dan strategi guna meminimalkan jumlah pajak terutangnya. Bentuk strategi yang dilakukan perusahaan untuk mengefisienkan beban pajak terutang yaitu dengan melakukan agresivitas pajak. Perusahaan dalam hal ini akan tetap membayarkan kewajiban pajaknya, namun perusahaan menggunakan strategi agresivitas pajak untuk meminimalkan beban pajak yang diperoleh.

Agresivitas pajak adalah strategi meminimalkan beban pajak dengan cara melakukan perencanaan pajak, dengan menggunakan cara legal (tax avoidance) atau ilegal (tax evasion) [1]. Agresivitas pajak berpotensi memberikan ancaman kepada penerimaan negara yang bersumber dari pajak. Hal ini berkaitan dengan fenomena terjadinya tindakan agresivitas pajak pada perusahaan yang mengarah pada tindakan perencanaan pajak melalui cara ilegal (tax evasion). Sehingga dapat disimpulkan bahwa tujuan utama dari agresivitas pajak adalah membuat beban pajak yang diterima oleh perusahaan menjadi lebih rendah. Selain itu agresivitas pajak dapat dijadikan sebagai sarana penghematan biaya yang dikeluarkan oleh perusahaan untuk membayar pajak dan dapat meningkatkan kekayaan para pemegang saham. Perusahaan atau badan akan melakukan berbagai cara untuk meminimalkan beban pajak tersebut agar jumlah pajak yang dibayarkan menjadi berkurang, bahkan dengan menghindari beban pajak akan menyebabkan perusahaan lebih agresif terhadap pajak dan melakukan tindakan agresivitas pajak [2]

Kasus mengenai agresivitas pajak yang terjadi pada perusahaan-perusahaan di Indonesia contohnya kasus perusahaan IKEA. Bermula dari Uni Eropa yang menduga raksasa furnitur rumah tangga dan kantor itu menghindari pajak hampir €1 miliar atau sekitar Rp15,9 triliun selama tahun 2009 sampai 2014 atas penjualan ritelnya di Belanda. Dalam laporan yang diterima oleh Uni Eropa tahun lalu diketahui IKEA membentuk dua entitas bisnis yang terpisah di Belanda, Luksemburg dan Liechtenstein. Entitas bisnis tersebut memanfatkan skema pajak khusus untuk memindahkan uang dan keuntungan. Penyelidikan terhadap IKEA inimerupakan kasus terbaru di mana perusahaan multinasional dapat memotong kewajiban pajak mereka. Aksi ini dianggap ilegal karena perusahaan domestik danlokal tidak dapat melakukan hal serupa, sehingga Komisi Kompetisi Uni Eropa menganggapnya sebagai keuntungan 
ilegal. IKEA disebut membayar pajak sebesar €825 miliar hingga bulan Agustus 2017 atas keuntungan mereka sebesar €3,31 triliun. Kasus terbaru ini melengkapi kasus penghindaran pajak memanfaatkan kebijakan negara. (Sumber: news.ddtc.co.id) [3].

Tindakan yang dilakukan oleh perusahaan tidak semuanya melanggar peraturan, namum semakin banyak celah yang dipergunakan atau semakin besar penghematan yang dilakukan maka perusahaan tersebut dianggap semakin agresif terhadap pajak. Untuk melihat bagaimana usaha dari perusahaan untuk melakukan agresivitas pajak dapat diukur melalui beberapa faktor, yaitu leverage, intensitas persediaan, intensitas aset tetap, profitabilitas, dan likuiditas.

Leverage adalah nama lain dari rasio utang. Menurut [4], leverage merupakan rasio yang digunakan untuk mengukur sejauhmana Aktiva perusahaan dibiayai dengan utang. Leverage adalah tingkat hutang yang dilakukan perusahaan untuk melakukan pembiayaan, rasio hutang dihitung dengan membandingkan antara total hutang dengan aktiva perusahaan, rasio tersebut menggambarkan bagaimana sumber dana operasi perusahaan [5]. Perusahaan dapat menggunakan tingkat leverage untuk mengurangi laba sehingga beban pajak berkurang [6]. Tidak semua penelitian yang dilakukan menemukan pengaruh leverage dengan agresivitas pajak. Hasil penelitian [7] membuktikan bahwa Leverage berpengaruh positif signifikan terhadap agresivitas pajak. Namun, hasil penelitian oleh [8] menyatakan bahwa Leverage tidak memiliki pengaruh terhadap agresivitas pajak.

Intensitas persediaan dapat diartikan sebagai besarnya pengukuran persediaan yang diinvestasikan pada perusahaan. Tingginya intensitas persediaan akan menjadi tambahan beban bagi perusahaan. Hal ini timbul karena adanya biaya persediaan. Semakin besar biaya persediaan yang dikeluarkan oleh perusahaan akan mengurangi laba bersih sehingga pembayaran pajakakan menurun. Namun apabilatidakterdapatfaktor pengurangan pajak pada suatu perusahaan maka jumlah pembayaran pajak akan meningkat [9]. Hasil penelitian yang dilakukan oleh [8] menyatakan bahwa intensitas persediaan berpengaruh positif signifikan terhadap agresivitas pajak. Sedangkan hasil penelitian oleh [10] menyatakan bahwa intensitas persediaan tidak berpengaruh terhadap agresivitas pajak.

Intensitas aset tetap yang tinggi menggambarkan semakin besar investasi perusahaan tersebut terhadap aset tetap. Banyaknya aset tetap yang dimiliki oleh perusahaan mengakibatkan beban depresiasi yang ditanggung akan besar. Hal ini menjadikan laba perusahaan akan semakin berkurangnya. Beban depresiasi dapat digunakan sebagai pengurang pajak sehingga pajak yang dibayarkan oleh perusahaan semakin kecil. Penelitian yang dilakukan oleh [11] menyatakan bahwa intensitas aset tetap berpengaruh positif terhadap agresivitas pajak. Penelitian ini didukung oleh [10]. Hasil penelitian [12] mengenai pengaruh intensitas aset tetap terhadap agresivitas pajak yang menunjukkan hasil berbeda yaitu bahwa intensitas aset tetap tidak berpengaruh terhadap agresivitas pajak. Penelitian ini mendukung penelitian yang dilakukan oleh [7].

Profitabilitas merupakan kemampuan perusahaan dalam mengelola aset untuk menghasilkan laba pada tahun berjalan. Semakin tinggi tingkat profitablitas dapat menjadi daya tarik investor untuk menanamkan modalnya di perusahaan tersebut. Hal ini dianggap bahwa kinerja manajemen dalam mengelola operasional perusahaan berhasil. Profitabilitas dianggap menjadi salah satu faktor yang mempengaruhi agresivitas pajak. Semakin tinggi laba yang diperoleh perusahaan maka pajak yang 
dibayarkan akan semakin tinggi. Profitabilitas yang tinggi akan mempengaruhi perusahaan untuk mengambil tindakan tentang beban pajak yang akan dibayarkan. Hal tersebut sejalan dengan hasil penelitian yang dilakukan oleh [13] bahwa pro fitabilitas berpengaruh signifikan positif terhadap agresivitas pajak. Namun bertentangan dengan hasil penelitian yang dilakukan oleh [14] yang menunjukkan bahwa profitabilitas tidak berpengaruh signifikan terhadap agresivitas pajak.

Kondisi keuangan perusahaan yang dianggap dapat memepengaruhi agresivitas pajak adalah likuiditas. Likuditas adalah kemampuan perusahaan dalam memenuhi kewajiban jangka pendek yang dimiliki. Perusahaan yang memiliki jumlah aktiva lancer lebih besar dari jumlah hutang lancarnya dapat dikatakan bahwa perusahaan tersebut memiliki tingkat likuiditas yang tinggi. Sehingga dapat diprediksi bahwa perusahaan mampu untuk membayar pajaknya. Apabila tingkat likuiditas rendah menggambarkan kemampuan perusahaan dalam memenuhi hutang lancarnya kurang baik, sehingga kemungkinan perusahaan akan melakukan tindakan agresivitas pajak untuk meminimalkan beban pajaknya agar likuiditas perusahaan membaik. Tidak semua penelitian yang dilakukan menemukan pengaruh likuiditas dengan agresivitas pajak. Hasil penelitian [8] membuktikan bahwa likuiditas berpengaruh negatif signifikan terhadap agresivitas pajak. Namun, hasil penelitian oleh [11] menyatakan bahwa likuiditas tidak memiliki pengaruh terhadap agresivitas pajak.

Ketentuan mengenai pajak menjadi penting ketika digunakan perusahaan dalam mengambil kebijakan maupun keputusan agar perusahaan tersebut terhindar dari tindakan agresivitas pajak serta sanksi perpajakan yang berlaku. Sehingga perusahaan akan lebih berhati-hati dalam melakukan tindakan mengenai pembayaran pajak agar laba yang diperoleh perusahaan tetap opimal dengan tidak melanggar ketentuan pajak tersebut. Sedangkan bagi investor ketentuan pajak ini dapat digunakan sebagai pandangan bagaiamana manajemen perusahaan dalam mengambil keputusan mengenai perpajakan dan memilih perusahaan yang tepat untuk berinvestasi.

Banyaknya perusahaan yang melakukan berbagai strategi dalam tindakan agresivitas pajak memberikan perhatian khusus kepada Direktorat Jenderal Pajak (DJP) dan Otoritas Jasa Keuangan (OJK). Hal ini dapat digunakan sebagai masukan bagi lembaga yang terkait untuk memperbaiki regulasi perpajakan bagi wajib pajak. Sehingga dapat memberikan wawasan mengenai faktor-faktor yang mempengaruhi agresivitas pajak dan dapat digunakan dalam mengambil kebijakan perpajakan untuk masa yang akan datang. Penelitian ini dapat digunakan sebagai wadah pengembangan ilmu ekonomi, khususnya bidang perpajakan serta menambah kajian maupun ilmu pengetahuan mengenai tindakan agresivitas pajak.

Berdasarkan pada penjelasan diatas yang didasarkan pada fenomena kondisi empirik, maka penelitian ini akan menguji mengenai pengaruh antara leverage, intensitas persediaan, intensitas aset tetap, profitabilitas, dan likuiditas terhadap agresivitas pajak. Penelitian ini dilakukan pada perusahaan manufaktur sektor industri yang terdaftar di Bursa Efek Indonesia (BEI) selama tahun 2017-2020. 


\section{Tinjauan Literatur}

\section{Teori keagenan (agency theory)}

Agency Theory atau Teori Keagenan menyatakan bahwa perbedaan kepentingan dengan principal dan agen dapat mempengaruhi berbagai hal yang menyangkut kinerja perusahaan seperti kebijakan perusahaan mengenai pajak [15]. Dalam tindakan agresivitas pajak, agen akan memanipulasi laporan keuangan perushaan agar pajak yang dibayarkan menjadi lebih kecil. Sedangkan principal menginginkan agar agen bekerja sesuai dengan prosedur yang ada dalam perusahaan.

\section{Agresivitas Pajak}

Agresivitas pajak adalah tindakan-tindakan yang dilakukan oleh perusahaan untuk mengurangi kewajiban pajaknya. Menurut [1], mendefinisikan bahwa agresivitas pajak adalah suatu tindakan perencanaan pajak yang dilakukan dengan cara legal maupun ilegal dengan tujuan untuk menurunkan laba kena pajak. Namun tidak semua perusahaan yang melakukan tindakan perencanaan pajak (tax planning) dapat dianggap melakukan agresivitas pajak. Tindakan agresivitas pajak dapat terbagi menjadi dua, yaitu:

\section{Pengindaran pajak (tax avoidance)}

Harry Graham Balter, mendefinisikan sebagai serangkaian tindakan wajib pajak dalam rangka mengurangi atau bahkan menghapus semua utang pajak dengan cara tertentu yang tidak melanggar undang-undang.

\section{Penggelapan Pajak (Tax Evasion)}

Penggelapan pajak dapat diartikan sebagai suatu tindakan perlawanan pajak yang dengan sengaja mengurangi jumlah pajak terutang bahkan meniadakan kewajiban membayar pajaknya secara ilegal dengan melanggar ketentuan perpajakan.

\section{Leverage}

Leverage adalah suatu rasio yang menggambarkan hubungan antara utang perusahaan terhadap modal maupun aset perusahaan [16]. Perusahaan dengan tingkat leverage yang tinggi dapat dikatakan bahwa perusahaan tersebut bergantung pada pinjaman atau utang, sedangkan perusahaan dengan tingkat leverage yang rendah berati perusahaan tesebut mampu membiayai asetnya dengan modal yang dimiliki. Tingkat leverage suatu perusahaan dapat dijadikan sebagai gambaran risiko keuangan perusahaan.

\section{Intensitas Persediaan}

Intensitas Perusahaan menggambarkan jumlah persediaan yang dibutuhkan perusahaan yang diukur dengan cara membandingkan total persediaan dengan total aset yang dimiliki perusahaan. Persediaan merupakan salah satu aset yang penting bagi perusahaan karena berfungsi sebagai penunjang kegiatan operasional perusahaan dalam jangka panjang. Menurut [17] Persediaan meliputi aktiva berwujud yang dimiliki oleh perusahaan dengan tujuan untuk dijual kembali atau dapat digunakan dalam proses produksi. 


\section{Intensitas Aset Tetap}

Aset tetap perusahaan menggambarkan jumlah aset yang dimiliki oleh perusahaan. Aset tetap menjadi komponen aset yang nilainya paling besar dalam laporan posisi keuangan (neraca). Intensitas aset tetap merupakan suatu rasio yang membandingkan antara intensitas kepemilikan aset tetap perusahaan dengan total aset. Perusahaan dapat mengurangi pajak dengan intensitas aset tetap karena adanya beban depresiasi yang melekat pada aset tersebut.

\section{Profitabilitas}

Profitabilitas adalah kemampuan perusahaan dalam menghasilkan keuntungan dalam suatu periode tertentu menggunakan modal yang cukup tersedia. Perusahaan dengan tingkat profitabilitas yang tinggi dapat dikatakan bahwa perusahaan tersebut memiliki kinerja manajerial yang baik. Salah satu indikator yang dapat digunakan untuk mengukur kemampuan perusahaan dalam menghasilkan laba yaitu dengan menggunakan ROA (Return On Asset). ROA dihitung dari laba setelah pajak dibagi dengan total aset perusahaan. Semakin tinggi nilai ROA suatu perusahaan, maka semakin tinggi laba dan profitabiltas perusahaan tersebut. Tingkat profitabilitas yang tinggi mengakibatkan pajak yang dibayarkan perusahaan menjadi tinggi pula.

\section{Likuiditas}

Rasio likuiditas merupakan kemampuan untuk memenuhi kewajiban jangka pendek dengan waktu yang telah ditetapkan [18]. Perusahan dengan tingkat rasio likuiditas yang tinggi dapat diartikan bahwa perusahaan tersebut memiliki kemampuan dalam memenuhi kewajiban jangka pendeknya dengan tepat waktu. Perusahaan tersebut dapat dapat dikatakan dalam keadaan likuid karena aktiva lancar yang dimiliki perusahaan lebih besar daripada hutang lancar. Likuditas dapat dihitung dengan membagi aktiva lancar perusahaan dengan liabilitas lancar perusahaan.

\section{Hipotesis Penelitian}

\section{Pengaruh Leverage terhadap Agresivitas Pajak}

Rasio Leverage dapat menggambarkan keadaan suatu perusahaan dalam memenuhi kewajiban jangka panjang maupun pendeknya, atau sejauh mana perusahaan dibiayai dengan hutang. Leverage menandakan perusahaan sedang berupaya untuk meningkatkan laba. Semakin tinggi laba pada perusahaan dapat berpengaruh terhadap agresivitas pajak. Jika perusahaan memiliki kewajiban yang besar maka perusahaan akan berupaya untuk meningkatnya laba agar dapat melunasi kewajibannya tersebut. Semakin tinggi laba yang diperoleh perusahaan maka pajak yang dibayarkan akan semakin tinggi pula. Sehingga perusahaan akan semakin lebih agresif untuk melakukan tindakan agresivits pajak.

Penelitian yang dilakukan oleh [7] menyatakan leverage berpengaruh positif signifikan terhadap agresivitas pajak. Mangacu pada penelitian [7] maka hipotesis yang diajukan adalah:

$\mathrm{H}_{1}$ : Leverage berpengaruh positif terhadap Agresivitas Pajak 


\section{Pengaruh Intensitas Persediaan terhadap Agresivitas Pajak}

Intensitas Persediaan merupakan jumlah persediaan yang dimiliki oleh perusahaan yang dibutuhkan untuk kegiatan operasional. Dalam teori agensi menyatakan bahwa dengan banyaknya persediaan manajer akan berupaya untuk meminimalisir beban pada perusahaan dengan tujuan agar laba yang diperoleh tidak menurun. Sedangkan di sisi lain manajer akan memaksimalkan biaya tambahan yang terpaksa ditanggung untuk menekan beban pajak.

Besarnya persediaan diharapkan dapat meningkatkan penjualan pada perusahaan. Semakin tinggi penjualan maka laba yang diperoleh akan semakin tinggi. Hal ini dapat mengakibatkan beban pajak yang diperoleh perusahaan semakin tinggi pula. Sehingga perusahaan akan berupaya untuk meminimalkan beban pajak pada periode tersebut dengan melakukan tindakan agresivitas pajak. Penelitian [8] mendapatkan hasil intensitas persediaan berpengaruh positif signifikan terhadap agresivitas pajak.

$\mathrm{H}_{2}$ : Intensitas Persediaan berpengaruh positif terhadap Agresivitas Pajak

\section{Pengaruh Intensitas Aset Tetap terhadap Agresivitas Pajak}

Intensitas aset tetap adalah seberapa besar proporsi aset tetap dari total aset yang dimiliki perusahaan [19]. Dalam meningkatkan keuntungan yang lebih maksimal, manajemen perusahaan akan menginvestasikan dana yang mengganggur di perusahaan ke dalam bentuk aset tetap. [20], menyatakan bahwa perusahaan dapat menggunakan aset tetap untuk tujuan operasioanal perusahaan maupun kegiatan perusahaan. Setiap tahunnya aset tetap tersebut menimbulkan beban penyusutan karena terdapat umur ekonomis, sehingga laba yang diterima perusahaan jumlahnya berkurang. Dengan adanya beban penyusutan (depresiasi) tersebut dapat mengurangi beban pajak yang terutang.

Semakin besar aset tetap suatu perusahaan, maka kemungkinan untuk membayar pajaknya lebih rendah dibandingkan dengan perusahaan yang memiliki aset tetap yang lebih sedikit. Hasil ini didukung oleh penelitian yang dilakukan oleh [11] serta [10] yang menunjukkan bahwa intensitas aset tetap berpengaruh positif signifikan terhadap agresivitas pajak.

$\mathrm{H}_{3}$ : Intensitas Aset Tetap berpengaruh positif terhadap Agresivitas Pajak

\section{Pengaruh Profitabilitas terhadap Agresivitas Pajak}

Profitabilitas merupakan kemampuan perusahaan dengan penjualan, modal sendiri, ataupun aktiva tetap untuk memperoleh laba yang maksimal [21]. Besarnya pajak yang dibayarkan oleh perusahaan tergantung pada besarnya laba yang diperoleh perusahaan tersebut. Sehingga semakin besar penghasilan, maka semakin besar pula pajak yang terutang. Perusahaan dapat meminimalkan beban pajak dengan melakukan perencanaan pajak atau tax planning agar pajak yang dibayarkan efisien.

Semakin besar profitabilitas suatu perusahaan, maka semakin besar pula peluang perusahaan untuk melakukan tindakan agresivitas pajak agar beban pajak yang diperoleh semakin kecil. Hasil penelitian yang telah dilakukan oleh [13] menunjukkan bahwa profitabilitas berpengaruh signifikan positif terhadap agresivitas 
pajak. Sedangkan menurut [22] menyatakan bahwa profitabilitas bepengaruh signifikan negatif terhadap agresivitas pajak.

$\mathrm{H}_{4}$ : Profitabilitas berpengaruh positif terhadap Agresivitas Pajak

\section{Pengaruh Likuiditas terhadap Agresivitas Pajak}

Likuiditas menggambarkan kemampuan perusahaan untuk memenuhi kewajiban jangka pendek yang bergantung pada arus kas [23]. Rasio likuiditas yang tinggi pada perusahaan menunjukkan bahwa perusahaan tersebut memiliki kondisi arus kas yang lancar. Penelitian yang dilakukan [24]-[26] memberikan bukti bahwa perusahaan yang mengalami kesulitan likuiditas kemungkinan tidak akan mematuhi peraturan perpajakan dan cenderung akan melakukan penghindaran pajak. Tindakan ini dilakukan karena perusahaan lebih mementingkan untuk mempertahankan arus kasnya dengan cara mengurangi pengeluaran pajaknya.

Penelitian yang dilakukan [22] menyatakan leverage berpengaruh negatif dan signifikan terhadap agresivitas pajak. Mangacu pada penelitian [22] maka hipotesis yang diajukan adalah:

$\mathrm{H}_{5}$ : Likuiditas berpengaruh negatif terhadap Agresivitas Pajak

\section{Metode Penelitian}

\section{Jenis Penelitian}

Penelitian ini menggunakan pendekatan kuantitatif. Penelitian kuantitatif merupakan penelitian yang menggunakan teknik pengambilan sampel secara random dan analisis datanya bersifat statistik. Penelitian ini dilakukan untuk menjelaskan pengaruh antara variabel independen leverage, intensitas persediaan, intensitas aset tetap, profitabilitas, dan likuiditas terhadap variabel dependen agresivitas pajak melalui pengujian hipotesis.

\section{Jenis dan Sumber Data}

Jenis data yang digunakan dalam penelitian ini adalah data sekunder. Data sekunder adalah sumber data yang diperoleh secara tidak langsung melalui media perantara. Sumber data yang digunakan berasal dari laporan keuangan tahunan perusahaan manufaktur sektor industri yang terdaftar di Bursa Efek Indonesia periode 2017-2020 yang bersumber dari situs resmi BEI yaitu www.idx.co.id

\section{Populasi dan Sampel}

Populasi dalam penelitian ini adalah perusahaan manufaktur sektor industri yang terdaftar di Bursa Efek Indonesia selama periode 2017 sampai 2020 dengan total populasi 53 perusahaan. Teknik pengambilan sampel menggunakan metode purposive sampling, dimana metode tersebut menggunakan kriteria sebagai berikut:

1) Perusahaan manufaktur sektor industri yang terdaftar di Bursa Efek Indonesia (BEI) selama tahun 2017-2020.

2) Perusahaan manufaktur sektor industri yang konsisten menerbitkan laporan keuangan selama tahun 2017-2020.

3) Perusahaan manufaktur sektor indutri yang memiliki laporan keuangan 
lengkap.

4) Perusahaa manufaktur sektor industri yang menggunakan satuan mata uang rupiah dalam laporan keuangannya selama tahun 2017-2020.

\section{Teknik Analisis Data}

Teknik analisis data pada penelitian ini menggunakan alat analisis regresi data panel karena penelitian ini menggunakan data dari beberapa individu yang sama yang diamati dalam kurun waktu tertentu. Penelitian ini menggunakan alat bantu program Eviews 9.

\section{Definisi Operasional dan Pengukuran Variabel}

Tabel 1. Definisi Operasional dan Pengukuran

\begin{tabular}{|c|c|c|c|}
\hline No. & Variabel & Definisi Operasional & Pengukuran \\
\hline 1. & Agresivitas Pajak & $\begin{array}{l}\text { Agresivitas pajak merupakan upaya } \\
\text { yang dilakukan oleh perusahaan untuk } \\
\text { meminimalkan beban pajak dengan } \\
\text { cara legal maupun illegal. Dalam } \\
\text { penelitian ini agresivitas pajak } \\
\text { diproksikan dengan menggunakan Net } \\
\text { Profit Margin (NPM). }\end{array}$ & $\mathrm{NPM}=\frac{\text { laba Bresih Setelah Pajak }}{\text { Penjualan Bersih }} \times 100 \%$ \\
\hline 2. & Leverage & $\begin{array}{l}\text { Leverage menggambarkan proporsi } \\
\text { hutang jangka panjang terhadap total } \\
\text { aset yang dimiliki perusahaan. }\end{array}$ & $L E V=\frac{\text { Total Hutang }}{\text { Total Aset }}$ \\
\hline 3. & Intensitas Persediaan & $\begin{array}{l}\text { Intensitas persediaan menggambarkan } \\
\text { besarnya persediaaan yang di } \\
\text { investasikan pada perusahaan untuk } \\
\text { kegiatan operasional. }\end{array}$ & INV $=\frac{\text { Total Persediaan }}{\text { Total Aset }}$ \\
\hline 4. & Intensitas Aset Tetap & $\begin{array}{l}\text { Intensitas aset tetap menggambarkan } \\
\text { besarnya nilai aset pada perusahaan } \\
\text { yang diinvestasikan dengan bentuk aset } \\
\text { tetap. }\end{array}$ & $\mathrm{IAT}=\frac{\text { Total Aset Tetap }}{\text { Total Aset }}$ \\
\hline 5. & Profitabilitas & $\begin{array}{l}\text { Profitabilitas merupakan kemampuan } \\
\text { suatu perusahaan dalam menghasilkan } \\
\text { laba yang diperoleh dari total aset yang } \\
\text { dimiliki perusahaan. }\end{array}$ & $\mathrm{ROA}=\frac{\text { Laba Bersih Setelah Pajak }}{\text { Total Aset }}$ \\
\hline 6. & Likuiditas & $\begin{array}{l}\text { Likuiditas menggambarkan kemampuan } \\
\text { arus kas pada perusahaan yang } \\
\text { diperoleh dengan membandingkan total } \\
\text { aset lancar dengan total hutang lancar } \\
\text { perusahaan. }\end{array}$ & $\mathrm{CR}=\frac{\text { Aset Lancar }}{\text { Hutang Lancar }}$ \\
\hline
\end{tabular}




\section{Hasil Dan Pembahasan}

\section{Statistika Deskriptif}

Tabel 2. Statistika Deskriptif

\begin{tabular}{|l|c|c|c|c|c|c|}
\hline & NPM & LEV & INV & INT & ROA & CR \\
\hline Mean & -0.070512 & 0.581389 & 0.214131 & 0.382151 & 0.035161 & 5.685709 \\
Median & 0.025011 & 0.522801 & 0.173993 & 0.307672 & 0.021931 & 1.519649 \\
Maximum & 3.987624 & 4.941777 & 0.580382 & 1.674828 & 0.794059 & 303.2819 \\
Minimum & -7.84657 & 0.003453 & 0.000000 & 0.000951 & -0.391843 & 0.084554 \\
Std. Dev. & 1.114519 & 0.579320 & 0.137331 & 0.260369 & 0.143331 & 32.92351 \\
Observations & 84 & 84 & 84 & 84 & 84 & 84 \\
\hline
\end{tabular}

Sumber: Output Eviews 9, 2021

Berdasarkan hasil analisis uji statistika deskriptif , variabel dependen agresivitas pajak menunjukkan standar deviasi sebesar 1.11. Sedangkan besarnya nilai minimum pada agresivitas pajak yaitu -7.84, nilai maksimum 3.98, dan nilai rata-rata (mean) adalah 0.07. Pada variabel independen leverage memiliki nilai standar deviasi sebesar 0.57 , nilai minimum 0.00, dan nilai maksimum adalah 4.94. Selain itu leverage menunjukkan nilai rata-rata (mean) sebesar 0.58. Variabel independen intensitas persediaan memiliki nilai standar deviasi sebesar 0.13 , nilai minimum 0.00 , dan nilai maksimum sebesar 0.58 , sedangkan besarnya nilai rata-rata (mean) adalah 0.21 .

Variabel independen lainnya yaitu intensitas aset tetap memiliki nilai standar deviasi sebesar 0.26 , nilai minimum 0.00 , dan untuk nilai maksimum sebesar 1.67 . Nilai rata-rata (mean) pada variabel intensitas aset tetap yaitu 0.38. Sedangkan untuk variabel independen profitabilitas menunjukkan nilai standar deviasi sebesar 0.14 , nilai minimum -0.39 , dan nilai maksimumnya 0,79 . Besarnya nilai rata-rata (mean) variabel profitabilitas yaitu 0.03 . Pada variabel independen likuiditas memiliki nilia standar deviasi sebesar 32.92, dengan nilai minimum 0.08, dan nilai maksimum 303.28, sedangkan nilai rata-rata sebesar 5.68.

\section{Uji Asumsi Klasik}

\section{Uji Multikolinieritas}

Tabel 3. Uji Multikolinieritas

\begin{tabular}{|c|c|c|c|c|c|}
\hline & LEV & INV & INT & ROA & CR \\
\hline LEV & 1 & 0.075507984 & 0.586897409 & 0.335530742 & - \\
INV & 0.075507984 & 1 & -0.17981355 & 0.055440895 & 0.17783131 \\
& & & & - \\
INT & 0.586897409 & -0.17981355 & 1 & -0.02028009 & - \\
ROA & 0.335530742 & 0.055440895 & -0.02028009 & 1 & -0.001112 \\
CR & -0.13251868 & -0.17783131 & -0.18861607 & -0.001112 & 1 \\
\hline
\end{tabular}

Sumber: Output Eviews 9, 2021 
Berdasarkan uji multikolinieritas diatas, diketahui bahwa besarnya nilai koefisien korelasi antar variabel independen kurang dari 0,08. Maka dapat disimpulkan bahwa tidak terjadi masalah multikolinieritas.

\section{Uji Heterokedastisitas}

Tabel 4. Uji Heterokedastisitas

Dependent Variable: RESABS

Method: Panel Least Squares

Date: 10/28/21 Time: 09:59

Sample: 20172020

Periods included: 4

Cross-sections included: 21

Total panel (balanced) observations: 84

\begin{tabular}{|c|c|l|r|r|}
\hline \multicolumn{1}{|c|}{ Variable } & Coefficient & Std. Error & \multicolumn{1}{|c|}{ t-Statistic } & \multicolumn{1}{c|}{ Prob. } \\
\hline C & 0.284491 & 0.209206 & 1.359858 & 0.1778 \\
LEV & -0.133968 & 0.184594 & -0.725740 & 0.4702 \\
INV & -1.027799 & 0.593792 & -1.730908 & 0.0874 \\
INT & 1.224082 & 0.399965 & 3.060474 & 0.0030 \\
ROA & -0.937620 & 0.589372 & -1.590880 & 0.1157 \\
CR & -0.000770 & 0.002415 & -0.318910 & 0.7506 \\
\hline R-squared & 0.245281 & Mean dependent var & 0.416061 \\
Adjusted R-squared & 0.196902 & S.D. dependent var & 0.774343 \\
S.E. of regression & 0.693933 & Akaike info criterion & 2.175866 \\
Sum squared resid & 37.56035 & Schwarz criterion & 2.349496 \\
Log likelihood & -85.38639 & Hannan-Quinn criter. & 2.245664 \\
F-statistic & 5.069952 & Durbin-Watson stat & 1.232655 \\
Prob(F-statistic) & 0.000447 & & \\
\hline
\end{tabular}

Sumber: Output Eviews 9, 2021

Berdasarkan hasil uji heterokedastisitas diatas, diketahui beberapa koefisien parameter variabel independen bersifat tidak signifikan. Besarnya nilai probabilitas>tingkat signifikan 0,05. Maka dapat dikatakan bahwa tidak terjadi masalah heterokedastisitas.

\section{Uji Regresi}

\section{Uji Chow}

Pada regresi data panel dapat dilakukan dengan tiga model, yaitu Common Effect Model (CEM), Fixed Effect Model (FEM), dan Random Effect Model (REM). Uji Chow dilakukan untuk mengetahui model mana yang akan digunakan antara common effect atau fixed effect pada cross section panel option. 
Tabel 5. Uji Chow

\begin{tabular}{|c|c|c|c|}
\hline $\begin{array}{l}\text { Redundant Fixed Effects T } \\
\text { Equation: Untitled } \\
\text { Test cross-section fixed ef }\end{array}$ & & & \\
\hline Effects Test & Statistic & d.f. & Prob. \\
\hline $\begin{array}{l}\text { Cross-section F } \\
\text { Cross-section Chi-square }\end{array}$ & $\begin{array}{r}1.228098 \\
29.660904\end{array}$ & $\begin{array}{r}(20,58) \\
20\end{array}$ & $\begin{array}{l}0.2660 \\
0.0755\end{array}$ \\
\hline
\end{tabular}

Sumber: Output Eviews 9, 2021

Berdasarkan hasil uji chow diatas, nilai Cross-section chi-square lebih besar dibandingkan dengan nilai Probabilitas maka dapat disimpulkan bahwa $0.0755>0.05$ artinya berdasarkan Uji Chow model CEM lebih tepat dibandingkan dengan FEM. Sehingga apabila terpilih model CEM maka dilanjutkan ke Uji Lagrange Multiplier untuk mengetahui model mana yang terbaik antara common effect model (CEM) atau random effect model (REM).

\section{Uji Lagrange Multiplier}

Setelah mengetahui hasil uji chow yang menunjukkan model common effect (CEM) yang terbaik, maka selanjutkan dilakukan uji lagrange multiplier untuk mengetahui model yang akan digunakan.

Tabel 6. Uji Lagrange Multiplier

\begin{tabular}{|c|c|c|c|}
\hline \multicolumn{4}{|c|}{$\begin{array}{l}\text { Lagrange Multiplier Tests for Random Effects } \\
\text { Null hypotheses: No effects } \\
\text { Alternative hypotheses: Two-sided (Breusch-Pagan) and one-sided } \\
\text { (all others) alternatives }\end{array}$} \\
\hline & \multicolumn{3}{|c|}{ Test Hypothesis } \\
\hline Breusch-Pagan & $\begin{array}{c}\text { Cross-section } \\
0.212378 \\
-0.6449\end{array}$ & $\begin{array}{c}\text { Time } \\
0.188800 \\
-0.6639\end{array}$ & $\begin{array}{c}\text { Both } \\
0.401179 \\
-0.5265\end{array}$ \\
\hline
\end{tabular}

Sumber: Output Eviews 9, 2021

Berdasarkan hasil uji lagrange multiplier diatas, nilai Both pada BreuschPagan (0.5265) lebih besar dari nilai Probabilitas (0.05) maka dapat disimpulkan bahwa $0.6223>0.05$ artinya berdasarkan Uji Lagrange Multiplier model common effect (CEM) lebih tepat dibandingkan dengan model random effect (REM) untuk mengestimasi regresi data panel. 
Tabel 7. Hasil Uji CEM

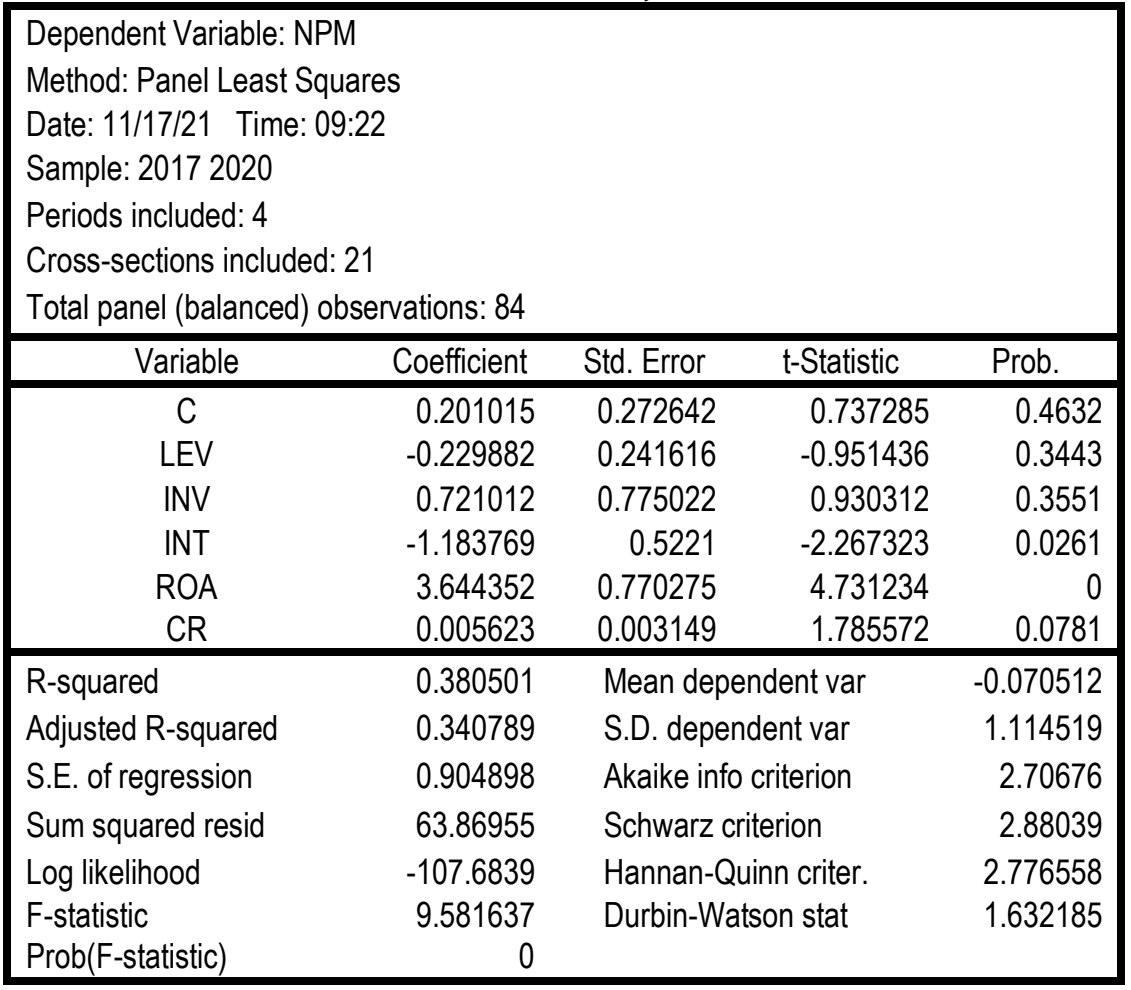

Sumber: Output Eviews 9, 2021

Berdasarkan hasil uji common effect model (CEM) diatas, dapat dilakukan uji hipotesis yang terdiri dari uji koefisien determinasi, Uji F, dan Uji t. Tujuan dari koefisien determinasi adalah untuk mengukur sejauh mana kemampuan model dalam menerangkan variabel dependen. Dari hasil uji CEM diatas, besarnya nilai Adjusted R Square adalah 0,340789 artinya kontribusi variabel independen leverage, intensitas persediaan, intensitas aset tetap, profitabilitas, dan likuiditas terhadap variabel dependen agresivitas pajak sebesar 34,07\%, sedangkan sisanya 65,93\% dijelaskan oleh variabel lain yang tidak dimasukkan dalam model tersebut. Nilai F hitung sebesar 9,58 lebih besar dari F tabel yaitu 2,85 atau nilai probabilitas 0,00 lebih kecil dari nilai alfa 0,05 yang menunjukkan bahwa secara simultan semua variabel independen berpengaruh signifikan terhadap variabel agresivitas pajak.

\section{Pembahasan}

\section{Peangaruh Leverage terhadap Agresivitas Pajak}

Berdasarkan hasil olah data tabel 5, hasil pengujian hiotesis 1 menunjukkan variabel leverage memiliki nilai koefisien sebesar $-0,229882$, dengan nilai t hitung $-0,951436<t$ tabel 2,131 dan nilai signifikannya 0,3443>tingkat signifikan 0,05. Hal ini berarti leverage tidak berpengaruh secara signifikan terhadap agresivitas pajak. Sehingga dapat dikatakan bahwa leverage bukan merupakan faktor penentu perusahaan dalam melakukan tindakan agresivitas pajak. Leverage dapat dijadikan sebagai tolak ukur seberapa besar perusahaan bergantung pada hutang (kreditur) dalam membiayai aktiva perusahaan. Semakin besar tingkat hutang yang dilakukan perusahaan tidak 
akan mempengaruhi tindakan agresivitas pajak. Hal ini menunjukkan bahwa perusahaan dapat dikatakan mandiri dan mampu mengoptimalkan kinerja perusahaan dan tidak bergantung pada hutang. Perusahaan yang memiliki hutang terlalu banyak akan menurunkan kepercayaan investor. Sehingga perusahaan harus mempertahankan labanya karena terkait dengan kepentingan kreditur. Hal ini tidak sesuai dengan teori agensi.

Berdasarkan teori agensi, principal tidak akan menyetujui apabila terdapat penambahan pendanan yang digunakan untuk kegiatan perusahaan. Sehingga pihak agent membutuhkan sumber dari pendanaan lain yang didapatkan dari utang agar dapat menutupi kekurangan dana tersebut. Kegiatan agen tersebut dengan menekan beban pajak perusahaan melalui pemanfaatan beban bunga. Hasil penelitian ini sejalan dengan penelitian yang dilakukan oleh [8] menyatakan bahwa Leverage tidak memiliki pengaruh terhadap agresivitas pajak. Namun berbeda dengan hasil penelitian yang dilakukan oleh [7] membuktikan bahwa Leverage berpengaruh positif signifikan terhadap agresivitas pajak.

\section{Pengaruh Intensitas Persediaan terhadap Agresivitas Pajak}

Hasil pengujian hipotesis 2 pada tabel 5 menunjukkan variabel intensitas persediaan memiliki nilai koefisien sebesar 0.721012 , dengan nilai t hitung $0.930312<\mathrm{t}$ tabel 2,131 dan nilai signifikannya 0.3551>tingkat signifikan 0,05. Maka dapat dikatakan bahwa tidak adanya pengaruh secara signifikan dari variabel intensitas persediaan terhadap agresivitas pajak. Penelitian ini sejalan dengan penelitian yang dilakukan oleh [10] yang menyatakan bahwa intensitas persediaan tidak berpengaruh terhadap agresivitas pajak. Tingkat persediaan pada suatu perusahaan tidak mempengaruhi jumlah beban pajak yang akan dibayarkan. Sehingga investasi dalam bentuk persediaan tidak tepat dilakukan karena tidak memberikan dampak terhadap tindakan agresivitas pajak. Persediaan yang disimpan terlalu lama akan menyebabkan penurunan nilai dalam akuntansi atau yang disebut dengan impairment asset (PSAK 48).

Jika dikaitan dengan teori agensi, penelitian ini tidak sesuai dengan teori tersebut. Berdasarkan teori agensi, perusahaan dengan tingkat perputaran persediaan yang tinggi akan menyebabkan adanya biaya tambahan yang akan diakui sebagai beban. Contohnya seperti biaya produksi, biaya tenaga kerja, biaya administrasi dan umum. Beban tersebut yang nantinya akan digunakan oleh perusahaan untuk mengurangi beban pajak yang akan dibayarkan. Namun penelitian ini bertolak belakang dengan penelitian yang dilakukan oleh [27] yang menyatakan bahwa intensitas persediaan berpengaruh negatif signifikan terhadap agresivitas pajak.

\section{Pengaruh Intensitas Aset Tetap terhadap Agresivitas Pajak}

Berdasarkan hasil olah data tabel 5, hasil pengujian hiotesis 3 menunjukkan variabel intensitas aset tetap memiliki nilai koefisien sebesar -1.183769 , dengan nilai t hitung $2.267323<\mathrm{t}$ tabel 2,131 dan nilai signifikannya $0.0261<$ tingkat signifikan 0,05 . Hal ini berarti intensitas aset tetap berpengaruh negatif dan signifikan terhadap agresivitas pajak. Semakin besar aset tetap yang dimiliki perusahaan, maka beban depresiasi yang ditanggung oleh perusahaan akan semakin besar pula. Adanya beban depresiasi akan 
mengurangi laba yang diperoleh perusahaan. Laba yang semakin rendah menyebabkan beban pajak yang diterima perusahaan akan semakin berkurang. Sehingga kemungkinan besar perusahaan tidak akan melakukan tindakan agresivitas pajak.

Jika dikaitkan dengan teori agensi, penelitian ini sesuai dengan teori tersebut. Berdasarkan teori agensi, perusahaan lebih menekan pada jumlah beban pajak. Manajer akan menggunakan dana yang menganggur untuk diinvestasikan dalam bentuk aset tetap. Hal ini bertujuan agar perusahaan memperoleh keuntungan melalui beban depresiasi yang akan digunakan sebagai pengurangan pajak. Penelitian ini sejalan dengan penelitian yang dilakukan oleh [28] yang menyatakan bahwa intensitas persediaan berpengaruh negatif terhadap agresivitas pajak. Namun berbeda dengan hasil penelitian yang dilakukan oleh [29] yang menyatakan bahwa intensitas aset tetap tidak memiliki pengaruh terhadap agresivitas pajak.

\section{Pengaruh Profitabilitas terhadap Agresivitas Pajak}

Hasil pengujian hipotesis 4 pada tabel 5 menunjukkan variabel profitabilitas memiliki nilai koefisien sebesar 3.644352, dengan nilai t hitung 4.731234>t tabel 2,131 dan nilai signifikannya $0.0000<$ tingkat signifikan 0,05. Maka dapat dikatakan bahwa adanya pengaruh positif dan signifikan dari variabel profitabilitas terhadap agresivitas pajak. Hasil penelitian ini sejalan dengan penelitian yang dilakukan oleh [13] bahwa profitabilitas berpengaruh signifikan positif terhadap agresivitas pajak. Dalam teori agensi, para stakeholders akan melihat sejauh mana perusahaan menghasilkan laba dari penjualan dan investasi perusahaan.

Perusahaan dengan tingkat profitabilitas tinggi dianggap bahwa kinerja manajemen dalam mengelola operasional perusahaan tersebut berhasil. Hal ini akan menciptakan respon positif kepada pemegang saham dan mengakibatkan harga saham perusahaan menjadi meningkat. Sehingga perusahaan akan mengambil tindakan untuk mengurangi beban pajaknya dengan melakukan agresivitas pajak. Semakin besar laba yang diperoleh perusahaan akan mengakibatkan beban pajak yang dibayarkan semakin besar pula. Namun penelitian ini bertolak belakang dengan penelitian yang dilakukan oleh [30] yang menyatakan bahwa profitabilitas tidak memiliki pengaruh terhadap agresivitas pajak.

\section{Pengaruh Likuiditas terhadap Agresivitas Pajak}

Berdasarkan hasil olah data tabel 5, hasil pengujian hiotesis 5 menunjukkan variabel likuiditas memiliki nilai koefisien sebesar 0.005623, dengan nilai t hitung $1.785572<\mathrm{t}$ tabel 2,131 dan nilai signifikannya $0.0781<$ tingkat signifikan 0,05. Hal ini berarti likuiditas tidak berpengaruh secara signifikan terhadap agresivitas pajak. Sehingga dapat dikatakan bahwa likuiditas bukan merupakan faktor penentu perusahaan dalam melakukan tindakan agresivitas pajak. Semakin tinggi tingkat likuiditas suatu perusahaan menunjukkan bahwa perusahaan mampu memenuhi kewajiban jangka pendeknya tepat pada waktunya yang bergantung pada arus kas. Sehingga perusahaan tidak mungkin untuk melakukan tindakan agresivitas pajak. Nilai likuiditas yang baik tidak menjadikan pajak sebagai beban biaya dalam perusahaan. 
Berdasarkan teori agensi, hubungan perusahaan dengan pihak ketiga (kreditur) akan membuat perusahaan untuk mempertahankan profitnya dengan tujuan menjaga kestabilan kinerja perusahaan. Hal ini dilakukan agar terjaganya hubungan baik dengan pihak ketiga dan mempercayai kembali perusahaan untuk melakukan kerja sama dimasa yang akan datang. Perusahaan yang berhutang cenderung kurang agresif terhadap pajaknya. Hasil penelitian ini sejalan dengan penelitian yang dilakukan oleh [11] menyatakan bahwa likuiditas tidak memiliki pengaruh terhadap agresivitas pajak. Namun berbeda dengan hasil penelitian yang dilakukan oleh [8] membuktikan bahwa likuiditas berpengaruh negatif signifikan terhadap agresivitas pajak. Sedangkan penelitian yang dilakukan oleh [31] menyatakan bahwa likuiditas berpengaruh positif signifikan terhadap agresivitas pajak.

\section{Kesimpulan Dan Saran Kesimpulan}

Berdasarkan hasil pengujian hipotesis yang telah dilakukan maka penelitian yang bertujuan untuk mengetahui pengaruh leverage, intensitas persediaan, intensitas aset tetap, profitabilitas, dan likuiditas terhadap agresvitas pajak pada perusahaan manufaktur sektor industri yang terdaftar di BEI pada periode 2017-2020 menghasilkan simpulan, antara lain: (1) leverage tidak berpengaruh secara signifikan terhadap agresivitas pajak, hal ini menunjukkan bahwa semakin besar tingkat hutang yang dilakukan perusahaan tidak akan mempengaruhi tindakan agresivitas pajak. (2) intensitas aset tetap tidak berpengaruh secara signifikan terhadap agresivitas pajak, karena tingkat persediaan pada suatu perusahaan tidak mempengaruhi jumlah beban pajak yang akan dibayarkan. Persediaan yang disimpan terlalu lama akan menyebabkan penurunan nilai dalam akuntansi. (3) intensitas aset tetap berpengaruh negatif dan signifikan terhadap agresivitas pajak, hal ini menunjukkan semakin besar aset tetap maka beban depresiasi akan semakin besar pula. Adanya beban depresiasi akan mengurangi laba perusahaan. Laba yang semakin rendah maka beban pajak yang diterima perusahaan akan semakin berkurang. (4) profitabilitas berpengaruh positif dan signifikan terhadap agresivitas pajak, karena tingkat profitabilitas tinggi menyebabkan laba yang diperoleh perusahaan semakin besar dan beban pajak yang dibayarkan semakin besar pula. (5) likuiditas tidak berpengaruh secara signifikan terhadap agresivitas pajak, hal ini menunjukkan semakin tinggi tingkat likuiditas suatu perusahaan menunjukkan bahwa perusahaan mampu memenuhi kewajiban jangka pendeknya tepat pada waktunya yang bergantung pada arus kas. Sehingga perusahaan tidak mungkin untuk melakukan tindakan agresivitas pajak.

\section{Keterbatasan}

Penelitian ini memiliki beberapa keterbatasan yaitu: (1) Obyek penelitian hanya dilakukan pada perusahaan sektor industri di BEI dengan penelitian yang terbatas yaitu selama 4 tahun yang terhitung pada tahun 2017-2020, sehingga data yang digunakan dalam penelitian ini relatif sedikit. (2) Penelitian ini memiliki nilai Adjusted R Square yang rendah sebesar $34,07 \%$ yang berarti bahwa kontribusi variabel independen yang digunakan dalam penelitian ini belum cukup baik dalam menjelaskan pengaruhnya terhadap agresivitas pajak. Sehingga masih banyak variabel lain yang 
dapat mempengaruhi agresivitas pajak selain variabel yang digunakan dalam penelitian ini.

\section{Saran}

Berdasarkan simpulan diatas, maka terdapat beberapa saran yang dapat dijadikan sebagai bahan pertimbangan penelitian di masa yang akan dating, yaitu sebagai berikut: (1) Penelitian selanjutnya disarankan menambahkan perusahaan yang bergerak pada sektor lain sebagai objek penelitian. (2) Peneliti selanjutnya disarankan meggunakan periode penelitian lebih dari 5 tahun. (3) Peneliti selanjutnya dapat menambahkan variabel independen lain yang kemungkinan dapat menjadi peluang perusahaan untuk melakukan tindakan agresivitas pajak. (4) Penelitian selanjutnya diharapkan dapat menggunakan proksi agresivitas pajak selain net profit margin (NPM), misalnya book tax defference (BTD), effective tax rate (ETR), cash effective tax rate (CETR), atau proksi lainnya.

\section{Referensi}

[1] M. M. Frank, L. J. Lynch, and S. O. Rego, "Tax reporting aggressiveness and its relation to aggressive financial reporting," Account. Rev., vol. 84, no. 2, pp. 467496, 2009, doi: 10.2308/accr.2009.84.2.467.

[2] S. Chen, X. Chen, Q. Cheng, and T. Shevlin, "Are Family Firms more Tax Aggressive than Non-family Firms?,” J. financ. econ., vol. 95, no. 1, pp. 41-61, 2010.

[3] D. A. Setiawan, "IKEA Terjerat Kasus Penghindaran Pajak," DDTC News, 2017. https://news.ddtc.co.id/kini-giliran-ikea-terjerat-kasus-penghindaran-pajak11556.

[4] Kasmir, Analisis Laporan Keuangan. Jakarta: PT. Raja Grafindo Persada, 2013.

[5] F. Irham, Analisis Laporan Keuangan. Bandung: Alfabeta, 2013.

[6] Brigham and Houston, Dasar-Dasar Manajemen Keuangan, Buku 1 (Ed. Jakarta: Salemba Empat, 2011.

[7] S. D. Pinareswati and T. Mildawati, "Pengaruh Pengungkapan CSR, Capital Intensity, Leverage, Profitabilitas, dan Inventory Intensity Terhadap Agresivitas Pajak," J. Ilmu dan Ris. Akunt., vol. 9, no. 9, pp. 1-23, 2020.

[8] I. F. Yuliana and D. Wahyudi, "Likuiditas, Profitabilitas, Leverage, Ukuran Perusahaan, Capital Intensity dan Inventory Intensity terhadap Agresivitas Pajak (Studi Empiris pada Perusahaan Manufaktur yang Terdaftar di Bursa Efek Indonesia Tahun 2013 - 2017)," Din. Akuntansi, Keuang. dan Perbank, vol. 7, no. 2, pp. 105-120, 2018.

[9] S. Imelia, "Analisis Faktor yang Mempengaruhi Manajemen Pajak dengan Indikator Tarif Pajak Efektif (ETR) pada Perusahaan LQ45 yang Terdaftar dalam Bursa Efek Indonesia Tahun 2010-2012," vol. 2, no. 1, p. 2015, 2015, [Online]. Available: http://weekly.cnbnews.com/news/article.html?no=124000.

[10] Efrinal and A. H. Chandra, "Pengaruh Capital Intensity dan Inventory Intensity terhadap Agresivitas Pajak," vol. 2, no. 2, pp. 135-148, 2020. 
[11] E. Kurniawan and L. Ardini, "Perngaruh Likuiditas, Leverage , Profitabilitas , Ukuran Perusahaan, Capital Intensity Terhadap Agresivitas Pajak," J. Ilmu dan Ris. Akunt., vol. 8, no. 9, pp. 1-20, 2019.

[12] D. A. M. Savitri and I. N. Rahmawati, "Pengaruh Leverage, Intensitas Persediaan, Intensitas Aset Tetap, dan Profitabilitas terhadap Agresivitas Pajak," vol. 8, no. 2, pp. 64-79, 2017.

[13] A. R. Herlinda and M. I. Rahmawati, "Pengaruh Profitabilitas, Likuiditas, Leverage dan Ukuran Perusahaan Terhadap Agresivitas Pajak," J. Ilmu Ris. Akunt., vol. 10, no. 1, pp. 1-18, 2021.

[14] I. Zenuari and M. Mranani, "Pengaruh Corporate Social Responsibility, Ukuran Perusahaan, Leverage, Profitabilitas, dan Capital Intensity Terhadap Agresivitas Pajak (Pada Perusahaan Manufaktur yang terdaftar di BEI Periode 20152019)," Bus. Econ. Conf. Util. Mod. Technol., pp. 1-83, 2020.

[15] M. C. Jensen and W. H. Meckling, "Theory of The Firm: Managerial Behavior, Agency Costs and Ownership Structure," Hum. Relations, vol. 72, no. 10, pp. 1671-1696, 1976, doi: 10.1177/0018726718812602.

[16] S. S. Harahap, Analisis Kritis Atas Laporan Keuangan, Edisi 11. Jakarta: Rajawali Pers, 2013.

[17] L. M. Samryn, Pengantar Akuntansi, Cetakan Ke. Jakarta: Rajawali Pers, 2015.

[18] Kasmir, Analisis Laporan Keuangan, Edisi Pert. Jakarta: PT. Raja Grafindo Persada, 2017.

[19] G. N. Desi, "Pengaruh Likuiditas, Leverage, Profitabilitas, Ukuran Perusahaan Dan Capital Intensity Terhadap Agresivitas Pajak Perusahaan," Institut Agama Islam Negeri Surakarta, 2016.

[20] I. B. P. F. Adisamartha and N. Naniek, "Pengaruh Likuiditas, Leverage, Intensitas Persediaan Dan Intensitas Aset Tetap Pada Tingkat Agresivitas Wajib Pajak Badan," E-Jurnal Akunt., vol. 13, no. 3, pp. 973-1000, 2015.

[21] Munawir, Analisis Informasi Keuangan, Liberty. Yogyakarta, 2012.

[22] I. F. P. Ismail and Cahyaningsih, "Pengaruh Intensitas Modal, Profitabilitas, Likuiditas, dan Leverage terhadap Agresivitas Pajak," e-Proceeding Manag., vol. 7, no. 2, pp. 2936-2944, 2020.

[23] K. R. Subramanyam and J. J. Wild, Analisis Laporan 10 Keuangan, Edisi Sepu. Jakarta: Salemba Empat, 2013.

[24] C. F. Bradley, "An Empirical Investigation of Factors Affecting Corporate Tax Compliance Behavior," University of Alabama, 1994.

[25] F. O. P. Siahaan, "Faktor-Faktor yang Mempengaruhi Perilaku Kepatuhan Tax Professional dalam Pelaporan Pajak Badan pada Perusahaan Industri Manufaktur di Surabaya," Universitas Airlangga, 2005.

[26] K. D. Suyanto and Supramono, "Likuiditas, Leverage, Komisaris Independen, Dan Manajemen Laba Terhadap Agresivitas Pajak Perusahaan," J. Keuang. dan Perbank., vol. 16, no. 2, pp. 167-177, 2012, [Online]. Available: http://jurkubank.wordpress.com.

[27] S. S. Arizoni, V. Ratnawati, and Andreas, "The Effect of Accrual Earnings 
Management, Real Earnings Management and Inventory Intensity Towards Tax Aggressivity: The Moderating Role of Foreign Operation," Bilancia J. Ilm. Akunt., vol. 4, no. 1, pp. 35-47, 2020.

[28] Maskanah and Islahuddin, "The Influence of Leverage, Density of Fixed Assets and Independent Commissioners on Effective Companies Tax Rate in Indonesia," J. Account. Financ. Audit. Stud., vol. 5, no. 2, pp. 24-37, 2019, doi: 10.32602/jafas.2019.18.

[29] A. Prasetyo and S. Wulandari, "Capital Intensity, Leverage, Return on Asset, dan Ukuran Perusahaan Terhadap Agresivitas Pajak," J. Akunt., vol. 13, no. 1, pp. 134-147, 2021.

[30] A. T. Hidayat and E. F. Fitria, "Pengaruh Capital Intensity, Inventory Intensity, Profitabilitas dan Leverage Terhadap Agresivitas Pajak," Eksis, vol. 13, no. 2, pp. 157-168, 2018.

[31] D. A. P. K. Adiputri and N. W. A. Erlinawati, "Pengaruh Profitabilits, Likuiditas dan Capital Intensity terhadap Agresivitas Pajak," Hita Akunt. dan Keuang., vol. 2, no. 2, pp. 467-487, 2021. 